\title{
Reflecting on Gold Geomicrobiology Research: Thoughts and Considerations for Future Endeavors
}

\author{
Jeremiah Shuster 1,2,*(i) and Frank Reith ${ }^{1,2}$ \\ 1 School of Biological Sciences, The University of Adelaide, Adelaide, SA 5005, Australia; \\ Frank.Reith@csiro.au \\ 2 CSIRO Land and Water, Contaminant Chemistry and Ecotoxicology, PMB2, Glen Osmond, \\ SA 5064, Australia \\ * Correspondence: jeremiah.shuster@adelaide.edu.au; Tel.: +61-8-8313-5352
}

Received: 13 August 2018; Accepted: 11 September 2018; Published: 13 September 2018

\begin{abstract}
Research in gold ( $\mathrm{Au})$ geomicrobiology has developed extensively over the last ten years, as more Au-bearing materials from around the world point towards a consistent story: That microbes interact with $\mathrm{Au}$. In weathering environments, Au is mobile, taking the form of oxidized, soluble complexes or reduced, elemental Au nanoparticles. The transition of Au between aqueous and solid states is attributed to varying geochemical conditions, catalyzed in part by the biosphere. Hence, a global Au-biogeochemical-cycle was proposed. The primary focus of this mini-review is to reflect upon the biogeochemical processes that contribute to what we currently know about Au cycling. In general, the global Au-biogeochemical-cycle begins with the liberation of gold-silver particles from a primary host rock, by physical weathering. Through oxidative-complexation, inorganic and organic soluble-Au complexes are produced. However, in the presence of microbes or other reductants-e.g., clays and Fe-oxides-these Au complexes can be destabilized. The reduction of soluble $\mathrm{Au}$ ultimately leads to the bioprecipitation and biomineralization of $\mathrm{Au}$, the product of which can aggregate into larger structures, thereby completing the Au cycle. Evidence of these processes have been "recorded" in the preservation of secondary Au structures that have been observed on $\mathrm{Au}$ particles from around the world. These structures-i.e., nanometer-size to micrometer-size $\mathrm{Au}$ dissolution and reprecipitation features-are "snap shots" of biogeochemical influences on Au, during its journey in Earth-surface environments. Therefore, microbes can have a profound effect on the occurrence of $\mathrm{Au}$ in natural environments, given the nutrients necessary for microbial metabolism are sustained and $\mathrm{Au}$ is in the system.
\end{abstract}

Keywords: gold-biogeochemical-cycling; microorganisms; bacteria; biomineralization; gold nanoparticles; soluble gold; secondary gold; gold dissolution/reprecipitation; gold transport; gold kinetic mobility; gold particles; gold nuggets

\section{Introduction}

Gold is a precious metal that has been sought-after since antiquity, due to its rarity, inertness, color, and malleability. With increasing advances in technology, Au has found a greater use in electronic and biomedical applications, which has contributed to the socioeconomic and cultural demand of this commodity. It has been estimated that $\mathrm{Au}$ has an average concentration ranging between $1.3-1.5 \mu \mathrm{g} / \mathrm{kg}^{-1}$ in the Earth's crust [1,2]. However, Au is not evenly distributed since deposits often contain Au concentrations $10^{4}$ times higher than the crustal average [1,3]. Gold deposits are broadly categorized as either primary or secondary. In general, primary Au deposits are often associated with quartz and polymetallic sulfide minerals, formed in high-pressure and temperature environments deep below the Earth's surface. When primary sources are subjected to uplift and/or physical weathering 
(e.g., eluvial, colluvial or (glacio)-fluvial processes), secondary Au deposits (i.e., placers) can eventually be formed. During weathering, Au is "liberated" and often occurs as variously-sized particles, also known as Au nuggets, grains, and flour Au [3-6]. It has been estimated that 183,000 tonnes of Au have been mined, with about a quarter being derived from secondary (placer) deposits [1]. Based on current global demands, the need to supply Au will continue well into the future, despite the increasingly reduced availability of conventional economically and environmentally-viable sources.

Bacteria and Archaea are considered to be the simplest form of life that are capable of metabolism. They have existed for billions of years and are ubiquitous in nature [7]. Metabolically-active microbes are capable of altering the geochemistry of their surrounding environment, for example, by catalyzing redox reactions, and adapting to conditions that would be considered extreme by other forms of life [8-11]. In terms of $\mathrm{Au}$ geomicrobiology, the earliest studies have shown that various microorganisms can solubilize Au (i.e., Chromobacterium violaceum [12]) or reduce soluble Au to form elemental Au nanoparticles (i.e., Bacillus subtilis [13]). These early studies have provided the basis for further research, demonstrating that Au dissolution and precipitation processes are often linked to the cycling of other elements, such as carbon, iron and sulphur [11,14-16]. More importantly, they have been important for the development of a hypothetical model that describes a global, Au-biogeochemical-cycle, driven by microbes [17]. In this holistic model, bacteria directly influence Au solubilization, Au-nanoparticle formation, nanoparticle aggregation, and $\mathrm{Au}$ (re)distribution within the natural environment. This model provides us with a perspective for viewing the mobility of $\mathrm{Au}$ and how it can "travel" under near-surface, environmental conditions.

From a materials perspective, the extent to which simple forms of life can influence the state of $\mathrm{Au}$ is remarkable, especially since this precious metal has traditionally been considered inert, and therefore, immobile. In light of these bacterial-Au interactions, it is worth considering greater applications of the biosphere with regards resource exploration and recovery. To date, biotechnology for industrial-scale Au production is underused [18,19]. Gold biogeochemistry will provide novel sampling-media, such as biosensors and bioindicators, or strategies to expand our current ability to trace $\mathrm{Au}$, during exploration. Applications such as these enhance detection of Au anomalies in natural soils and sediment, and identify additional targets for exploration [20]. An improved understanding of biogeochemical processes will also provide promising outcomes for the recovery of Au from materials that are conventionally considered waste (i.e., mine-tailings, sewage sludge, and outdated electronics).

Previous reviews on Au geomicrobiology have largely focused on fundamental processes for the purpose of potential exploration [14,21]. The objective of this mini-review is to highlight the influence of microbes on the biogeochemical cycling of Au under surface and near-surface conditions, by reflecting upon a variety of interdisciplinary studies that have contributed to the field of $\mathrm{Au}$ geomicrobiology. In doing so, we hope to provide a comprehensive glimpse of Au geomicrobiology and impart a greater appreciation of how life plays an important role in Au-biogeochemical-cycling.

\section{Soluble Gold Complexes}

Elemental $\mathrm{Au}$ is derived from primary or secondary sources. It can be dissolved in the presence of strong oxidizing agents and coordinating ligands, to form soluble- $\mathrm{Au}(\mathrm{I})$ or $\mathrm{Au}(\mathrm{III})$ complexes [22-25]. The formation of such complexes is dependent on the availability of oxidizing agents and ligands, which are influenced by the (bio)geochemistry of the surrounding environment [22,26-29]. From a geochemical perspective, chloride $\left(\mathrm{Cl}^{-}\right)$and thiosulfate $\left(\mathrm{S}_{2} \mathrm{O}_{3}{ }^{2-}\right)$ are considered the two-most-likely coordinating ligands for the solubilization of $\mathrm{Au}$. In saline to hypersaline environments, $\mathrm{AuCl}_{4}{ }^{-}$would likely be the dominant, soluble-Au complex, since excess $\mathrm{Cl}^{-}$ions would be available as a coordinating ligand [26] (Reaction (1)). However, in environments where $\mathrm{Cl}^{-}$ions are less abundant, thiosulfate $\left(\mathrm{S}_{2} \mathrm{O}_{3}{ }^{2-}\right)$ compounds are considered an important coordinating ligand that forms soluble $\mathrm{Au}\left(\mathrm{S}_{2} \mathrm{O}_{3}\right)_{2}{ }^{3-}$. Thiosulfate and other polythionates are produced during the (bio)oxidative weathering of metal sulphides. Therefore, $\left(\mathrm{S}_{2} \mathrm{O}_{3}{ }^{2-}\right)$ is reasonably considered to be a likely coordinating ligand, especially if elemental $\mathrm{Au}$ or $\mathrm{Au} / \mathrm{Ag}$ alloys are closely associated with primary, metal-sulfide minerals [26-28,30] 
(see Reactions (2) and (3). Note that $M$ represents metal). Cyanide $\left(\mathrm{CN}^{-}\right)$, an inorganic acid, can also act as a coordinating ligand to form $\mathrm{Au}(\mathrm{CN})_{2}{ }^{-}$, which has been detected in waters from Au mine-tailings and bores [24,31]. At mine sites, $\mathrm{CN}^{-}$can be derived from anthropogenic sources that were released during leaching processes, e.g., heap-leaching of Au-bearing ores [32]. In natural environments, some microbes, such as C. violaceum, are known to produce $\mathrm{CN}^{-}$as a by-product of metabolism and have been shown to solubilize elemental $\mathrm{Au}[12,33,34]$ (see Reaction (4)). It is important to note that under surface conditions, a number of organic Au complexes can occur. This is because organic acids, such as amino-, humic- and fulvic acids, can contribute to the solubilization of $\mathrm{Au}$ [35-40].

$$
\begin{gathered}
\mathrm{Au}^{0}{ }_{(\mathrm{s})}+4 \mathrm{Cl}^{-}{ }_{(\mathrm{aq})}+\frac{1}{2} \mathrm{O}_{2(\mathrm{aq})}+2 \mathrm{H}^{+}{ }_{(\mathrm{aq})} \rightarrow 2 \mathrm{AuCl}_{2}{ }_{(\mathrm{aq})}+\mathrm{H}_{2} \mathrm{O}_{(\mathrm{aq})} \\
\mathrm{MS}_{2(\mathrm{~s})}+6 \mathrm{M}^{3+}{ }_{(\mathrm{aq})}+3 \mathrm{H}_{2} \mathrm{O}_{(\mathrm{aq})} \rightarrow \mathrm{S}_{2} \mathrm{O}_{3}{ }^{2-}{ }_{(\mathrm{aq})}+7 \mathrm{M}^{2+}{ }_{(\mathrm{aq})}+6 \mathrm{H}^{+}{ }_{(\mathrm{aq})} \\
2 \mathrm{Au}^{0}{ }_{(\mathrm{s})}+2 \mathrm{~S}_{4} \mathrm{O}_{6}{ }^{2-}{ }_{(\mathrm{aq})}+2 \mathrm{H}_{2} \mathrm{O}_{(\mathrm{aq})}+\mathrm{M}^{2+}{ }_{(\mathrm{aq})} \rightarrow 2 \mathrm{Au}\left(\mathrm{S}_{2} \mathrm{O}_{3}\right)_{2}{ }^{3-}{ }_{(\mathrm{aq})}+4 \mathrm{H}^{+}{ }_{(\mathrm{aq})}+\mathrm{MO}_{2(\mathrm{~s})} \\
\mathrm{Au}^{0}+2 \mathrm{CN}^{-}{ }_{(\mathrm{aq})}+\frac{1}{2} \mathrm{H}_{2} \mathrm{O}_{(\mathrm{aq})}+\frac{1}{4} \mathrm{O}_{2(\mathrm{aq})} \rightarrow \frac{1}{4} \mathrm{Au}(\mathrm{CN})_{2}{ }_{(\mathrm{aq})}+\mathrm{OH}^{-}{ }_{(\mathrm{aq})}
\end{gathered}
$$

Hydrogeologic regimes are physically and chemically-dynamic systems. Therefore, it is important to consider that physical factors, such as convective mixing of different groundwaters, can affect the mobility and transport of soluble-Au complexes [23,41]. Chemical factors, such as ambient $\mathrm{pH}$, can influence the stability of soluble-Au complexes. For example, $\mathrm{Au}\left(\mathrm{S}_{2} \mathrm{O}_{3}\right)_{2}{ }^{3-}$ is generally more stable under $\mathrm{pH}$ neutral conditions, whereas $\mathrm{Au}(\mathrm{III})$-chloride complexes are more stable under acidic conditions [22]. Additionally, $\mathrm{Au}(\mathrm{I})$ complexes are generally considered to be less stable and more transitory, as they can readily dissociate into elemental $\mathrm{Au}$ and $\mathrm{Au}(\mathrm{III})$. The existence of $\mathrm{Au}(\mathrm{III}) \mathrm{has}$ been confirmed in circum-neutral, saline waters [24]. Therefore, the speciation of Au in any given environment must also be considered dynamic, as the formation of various soluble-Au complexes can occur. In the context of Au-biogeochemical-cycling, understanding how the formation of soluble Au occurs is important for understanding its mobility in near-surface environments.

\section{Gold Biomineralization and Biochemistry}

The dispersion and (re)concentration of metals in natural environments by biogeochemical processes was first suggested by Goldschmidt [42]. Approximately half a century later, microbial cell walls were identified as important structures separating intracellular and extracellular environments, as well as playing a role in mineral nucleation $[43,44]$. In general, the net negative charge of microbial cell surfaces is responsible for metal ionization and binding. This passive biomineralization mediated by biological systems is a mechanism in which mineral precipitates can nucleate on cellular "templates" [11,44,45]. In the context of Au biomineralization, multiple studies have assessed the reduction mechanisms and capacities of various metabolizing and non-metabolizing microorganisms, when exposed to a variety of different soluble-Au complexes [13,15,16,46-54]. The exposure of microbes to soluble-Au complexes often results in the extracellular or intracellular formation of nanophase $\mathrm{Au}^{0}$ colloids or crystals $[13,15,16,46-50]$, as seen in Figure 1 . These secondary-Au structures are formed, as organic material acts as a source of electrons, which can be stripped away by oxidized Au (see Reaction (5)). Therefore, cell envelopes function as kinetic factors that directly reduce soluble-Au complexes, forming elemental $\mathrm{Au}$ in the form of nanophase colloids, as well as crystalline structures. It is important to remember that heavy metals are often highly cytotoxic. This includes soluble-Au complexes. Soluble metals are capable of causing cells to lyse, thereby releasing intracellular material. When these organic materials are released into the surrounding environment, they can act as additional reducing-agents for the reduction of the soluble metal [16,55]. The resilience of biofilms to the toxic effects of soluble Au has been demonstrated [16]. Cells located at the biofilm-fluid-interface are often directly exposed to Au-bearing solutions. The reduction of soluble Au by cells at this interface protects cells deeper within the biofilm from the toxic effects of soluble Au. This suggests a sustained mode of 
Au biomineralization and highlights the potential for the mobility of Au as nanoparticles, as well as the accumulation of these nanoparticles to form larger structures. Therefore, in near-surface environments, biomineralization has the potential to be a continuous process, so long as the metabolic growth of microbes is sustained $[11,16]$.

$$
\mathrm{Au}^{+}{ }_{(\mathrm{aq})}+\mathrm{CHO}_{2}{ }^{-}(\mathrm{s}) \rightarrow \mathrm{Au}^{0}{ }_{(\mathrm{s})}+\mathrm{CHO}_{2(\mathrm{~s})}
$$

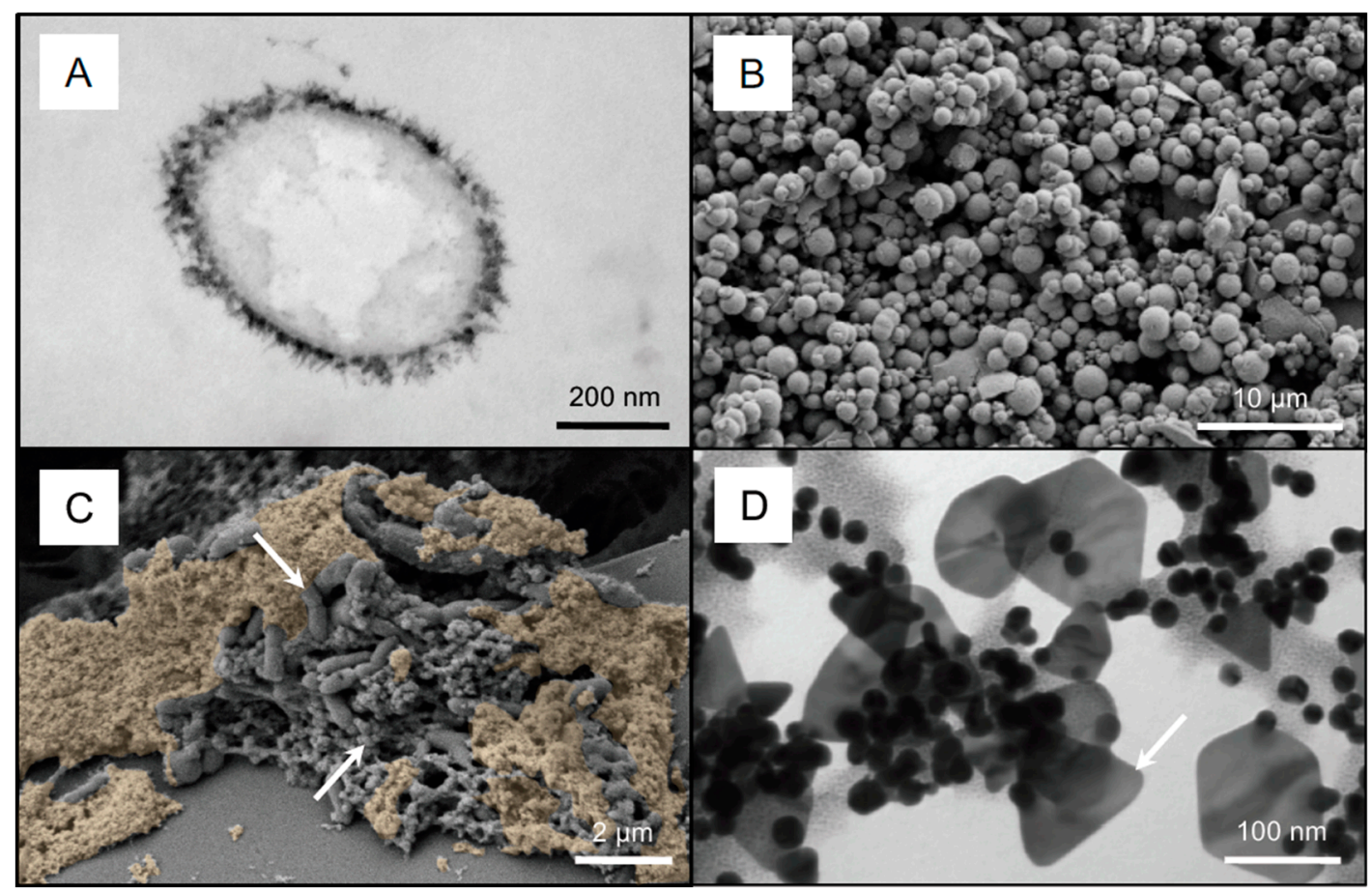

Figure 1. A Transmission Electron Microscopy (TEM) micrograph of an acidophilic, iron-oxidizing bacterium, mineralized in Au nanoparticles. These nanoparticles were produced by the reduction of $\mathrm{Au}(\mathrm{III})$-thiosulfate. Extracellular mineralization lead to the disruption of the cell membrane resulting in a "frayed" appearance (A) [15]. A low-magnification, secondary-election (SE) SEM micrograph of colloidal Au sulfide was produced by the iron-rich, spent medium of acidophilic, iron-oxidizing bacteria (B) [15]. A false-colored, SE SEM micrograph of a sulfate-reducing bacterial biofilm, coated with Au nanoparticles (highlighted in yellow) from the reduction of $\mathrm{Au}(\mathrm{III})$-chloride (C) [16]. Note the rod-shaped cells (upper arrow, (C)) and the associated iron sulfide mineral-precipitate (lower arrow, (C)). A high-magnification TEM micrograph of Au nanoparticles produced from the exposure of delftibactin to $\mathrm{Au}(\mathrm{III})$-chloride (D). Note the co-precipitation of quasi-spherical nanoparticles and octahedral platelets (arrow in (D)).

Microbes capable of iron or sulfur oxidation/reduction are considered important contributors to Au biomineralization, because the cycling of these elements is closely linked to the biogeochemical cycling of Au (Figure 1A) [15,16,49]. The active metabolism of these chemolithotrophic bacteria are known to make by-products that can reduce soluble $\mathrm{Au}$, and therefore, are considered an indirect mechanism of Au biomineralization. For example, acidophilic, iron-oxidizing bacteria generate increased concentrations of ferric iron and acidic conditions, which are both known to destabilize and subsequently reduce soluble Au(I)-thiosulfate, as shown in Figure 1A,B (see Reactions (6)-(9)) [15]. In a similar manner, iron sulfides produced by sulfate-reducing bacteria can reduce Au(III) chloride, as shown in Figure 1C (see Reaction (10)) [16]. Additionally, some metal-resistant microbes, such as the bacterium, Delftia acidovorans, are known to contribute to Au biomineralization by excreting secondary metabolites (e.g., delftibactin) into the extracellular environment to bind and reduce soluble $\mathrm{Au}$ [56]. This mode of Au biomineralization is a survival mechanism that can reduce soluble Au 
distally from the cell. Interaction of soluble Au with delftibactin produces nanophase Au in the form of pseudo-spheres and octahedral platelets, as shown in Figure 1D. Similarly, Cupriavidus metallidurans is a metallophilic bacterium that contributes to the bacterial diversity of biofilms living on the surface of Au particles from numerous sites, worldwide. It has been shown to mediate Au detoxification and biomineralization by a series of specific mechanisms [57-59]. In general, Au(III) complexes, as well as $\mathrm{Cu}$ (II) ions, can enter into the periplasmic space of bacterial cells. These soluble metals become reduced upon contact with the cell, forming $\mathrm{Au}(\mathrm{I})$ and $\mathrm{Cu}(\mathrm{I})$, respectively. They are then transported into the cytoplasm. While certain $\mathrm{Cu}(\mathrm{I})$ concentrations are beneficial for cells to carry out metabolic functions, a surplus of $\mathrm{Cu}$ is toxic and must be eliminated. As such, $\mathrm{Cu}(\mathrm{I})$ is transferred to the periplasm by P-type ATPase CupA and deposited to the cell's exterior by the trans-envelope efflux system, CusCBA. In the cytoplasm, $\mathrm{Au}(\mathrm{III})$ can bind to $\mathrm{CupC}$, thereby inhibiting the $\mathrm{Cu}(\mathrm{I})$ efflux pump, CupA [58]. This pump is then unable to export surplus cytoplasmic $\mathrm{Cu}(\mathrm{I})$. The inhibition of these pumps by $\mathrm{Au}(\mathrm{III})$ is responsible for the observed synergistic $\mathrm{Cu}$ and $\mathrm{Au}$ toxicity that can occur in auriferous environments [58]. Therefore, C. metallidurans is able to counteract the synergistic toxicity of cytoplasmic $\mathrm{Cu}(\mathrm{I})$ and $\mathrm{Au}(\mathrm{I})$ by $\mathrm{CopA}$ - and $\mathrm{O}_{2}$-dependent oxidation to $\mathrm{Au}(\mathrm{III})$. $\mathrm{Au}(\mathrm{III})$ is then exported to the periplasm, where it is directly reduced to nanophase $\mathrm{Au}^{0}$. These reactions reduce the toxicity of soluble-Au complexes by actively reducing soluble Au to its elemental form [60].

$$
\begin{gathered}
8 \mathrm{Fe}^{3+}{ }_{(\mathrm{aq})}+\mathrm{Au}\left(\mathrm{S}_{2} \mathrm{O}_{3}\right)_{2}{ }^{3-}{ }_{(\mathrm{aq})}+5 \mathrm{H}_{2} \mathrm{O}_{(\mathrm{aq})} \rightarrow \mathrm{Au}^{+}{ }_{(\mathrm{aq})}+\mathrm{S}_{2} \mathrm{O}_{3}{ }^{2-}{ }_{(\mathrm{aq})}+2 \mathrm{SO}_{4}{ }^{2-}{ }_{(\mathrm{aq})}+10 \mathrm{H}^{+}{ }_{(\mathrm{aq})} \\
\mathrm{S}_{2} \mathrm{O}_{3}{ }^{2-}{ }_{(\mathrm{aq})}+\mathrm{H}_{2} \mathrm{O}_{(\mathrm{aq})}+\mathrm{H}^{+}{ }_{(\mathrm{aq})} \rightarrow \mathrm{H}_{2} \mathrm{SO}_{4(\mathrm{aq})}+\mathrm{HS}^{-}{ }_{(\mathrm{aq})} \\
2 \mathrm{Au}^{+}{ }_{(\mathrm{aq})}+\mathrm{HS}^{-}{ }_{(\mathrm{aq})} \rightarrow \mathrm{Au}_{2} \mathrm{~S}_{(\mathrm{s})}+\mathrm{H}^{+}{ }_{(\mathrm{aq})} \\
\mathrm{Au}^{+}{ }_{(\mathrm{aq})}+\mathrm{Fe}^{2+}{ }_{(\mathrm{aq} / \mathrm{s})} \rightarrow \mathrm{Au}^{0}{ }_{(\mathrm{s})}+\mathrm{Fe}^{2+}{ }_{(\mathrm{aq})} \\
\mathrm{HAuCl}_{4(\mathrm{aq})}+\mathrm{FeS}_{(\mathrm{s})} \rightarrow \mathrm{Au}^{0}{ }_{(\mathrm{s})}+\mathrm{Fe}^{3+}{ }_{(\mathrm{aq})}+\mathrm{S}_{(\mathrm{aq})}+3 \mathrm{Cl}^{-}{ }_{(\mathrm{aq})}+\mathrm{HCl}_{(\mathrm{aq})}
\end{gathered}
$$

\section{Gold Particle Transformation}

A better understanding of Au-biogeochemical-cycling has been attained through a range of studies looking at the structure and chemistry of placer Au particles. Studies that have observed microbes on the surface of placer Au particles, as well as the detection of microbial communities, have provided additional insight into the biogeochemical cycling of $\mathrm{Au}$ [17,61-67]. Gold derived from a primary source, (e.g., hydrothermal or epithermal, Au-rich porphyry or Au-rich-porphyry-Cu deposits) often occurs as an alloy with varying amounts of silver (Ag). The Au:Ag ratio of these alloys is a signature that is indicative of the type of primary source from which the alloy was derived [5,68-71]. From epithermal sources, such as the San Salvador veins of the Capillitas mine, Au can occur as micrometer-sized, irregularly-shaped, Au-Ag inclusions that are hosted within a polymetallic sulfide mineral [72,73]. The dissolution of polymetallic sulfides is catalyzed by chemolithotrophic bacteria, such as iron- or sulfur-oxidizers [74-76]. It has been demonstrated that bacterially-catalyzed dissolution of Au-bearing metal sulfide minerals can release Au-Ag inclusions. In one study, liberated inclusions occurred as buoyant, hydrophobic particles. More importantly, this study highlighted the extent to which microbial processes could act on primary sources, thereby producing placer Au particles [77].

Although pure Au particles exist, placer Au particles from around the globe often contain three structural features: A Au-Ag alloy core, a Au-enriched rim, and secondary Au structures. While these features are common on all particles, their expression is highly variable and reflects the unique journey of transformation that this Au particle has undergone. The overall morphologies of Au particles have been described in terms of shape and length of the longest axes, perpendicular short axes, and heights. These physical qualities, attributed to mechanical reshaping, have been used as indicators for how far Au particles have been transported from their respective primary origin [68]. While Au:Ag ratios of cores reflect the origin of Au particles, Au-enrichment of particles reflect the extent of biogeochemical weathering that particles experienced under near-surface conditions. Gold 
enrichment is often characterized as rims that occur at the outer edge of particles in cross section. These rims can vary in thickness and are often composed of pure ( $>99$ wt \%) Au. Polymorphic layers are comprised of clay minerals, residual organic material, bacterial cells, and secondary Au structures. These layers often occur within crevices, which is to say, topographically-low regions, at the surface of Au particles $[64,66,67,78]$. Secondary Au structures are nanometer-micrometer-scale features that occur on Au particles. With increasing sophistication of electron microscopes, the characterization of these secondary Au structures has greatly improved, thereby providing a better understanding of Au-particle transformation. Secondary Au structures can be broadly categorized into two groups, based on the processes that contribute to their formation: $\mathrm{Au} / \mathrm{Ag}$ dissolution and $\mathrm{Au}$ reprecipitation. It is the balance between these two, biogeochemical processes that drives the cycling of $\mathrm{Au}$ and contributes to the transformation of Au particles. The solubilization of Au and Ag from Au particles (for example, by dealloying or (bacterially-catalyzed) solubilization) leads to the formation of dissolution features which include striations, porous structures, and bacteriomorphic Au [62,66,67,77,79,80]. These features are attributed to (bio)geochemical-dissolution processes, as striations often occur along Au crystal boundaries [80]. Bacteriomorphic Au also contains a crystalline fabric, containing both Au and $\mathrm{Ag}$, which is reminiscent of the primary material [66]. As previously mentioned, dissolved Au occurs as soluble-Au complexes that can be directly reduced by bacteria or other organic/inorganic reductants, to form pure, $\mathrm{Au}^{0}$ nanoparticles. While these nanoparticles often appear quasi-spherical in shape, they are actually nanophase crystals. At micrometer-scales, euhedral crystals are more clearly-defined and variability in structures is apparent, as shown in Figure 2. It is important to keep in mind that Au-dissolution processes, acting on a Au particle, can also act upon Au nanoparticles, thereby increasing structural variability. Therefore, it is reasonable to deduce that, with increased Au solubilization from an Au particle, subsequent reduction of the soluble complex will either form more abundant nanoparticles or allow nanoparticles to grow in size. Additionally, secondary Au structures can be physically altered during mechanical re-shaping, which suggests a balance between (bio)geochemical and mechanical weathering processes. Therefore, secondary Au structures are relicts - physical evidence of past, biogeochemical processes that have transformed particle surfaces and have attributed, in part, to the activity of microbes $[61,66,67,77,81]$, as shown in Figure 3. Interestingly, Au particles that exhibited a greater extent of transformation also contained biofilms with a more-specialized, metal-tolerant, microbial community [61,67]. Though Au is conventionally considered an inert metal, the interaction between microbes and Au particles highlights not only an influence of bacteria on Au-particle-structure and chemistry, but on microbial diversity as well, with regards increased resistance to Au toxicity.

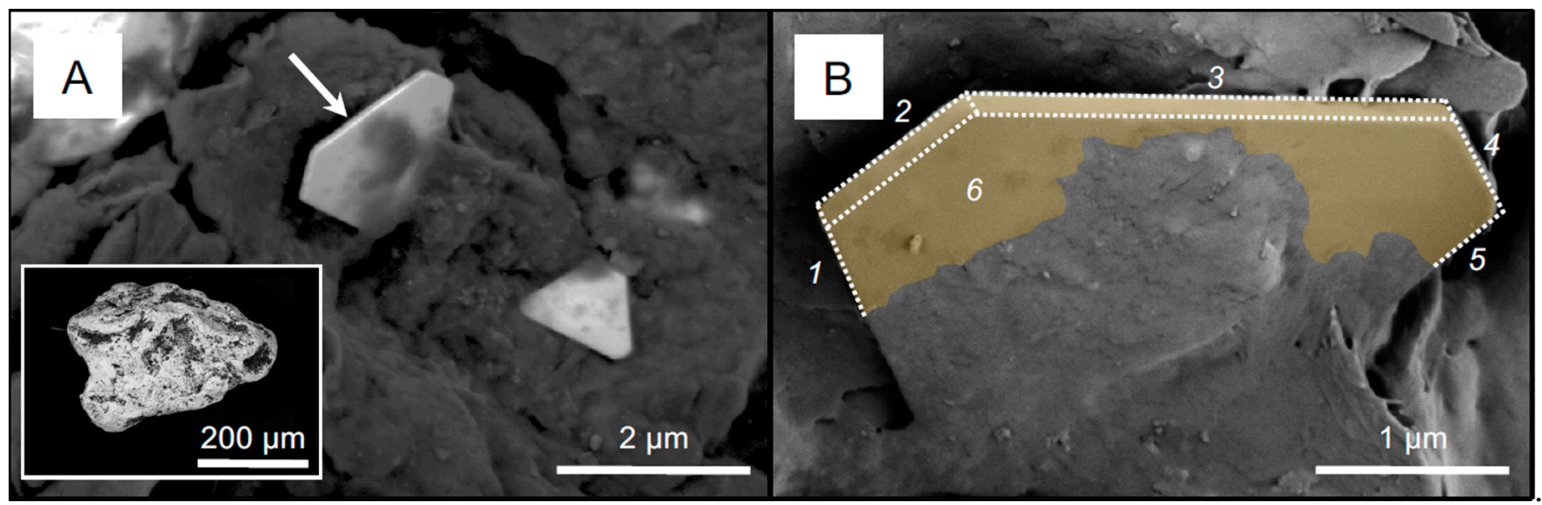

Figure 2. A high-magnification, BSC SEM micrograph of two octahedral, Au platelets, partially embedded within clay minerals (A). A false-colored BSC SEM micrograph of the octahedral platelet (arrow in (A)), rotated ca. $38^{\circ}$. The dashed lines highlight the six of the eight sides of this euhedral crystal (B) [64]. These types of nanoparticles commonly occur on the surface of placer Au particles (e.g., inset, (A)). 


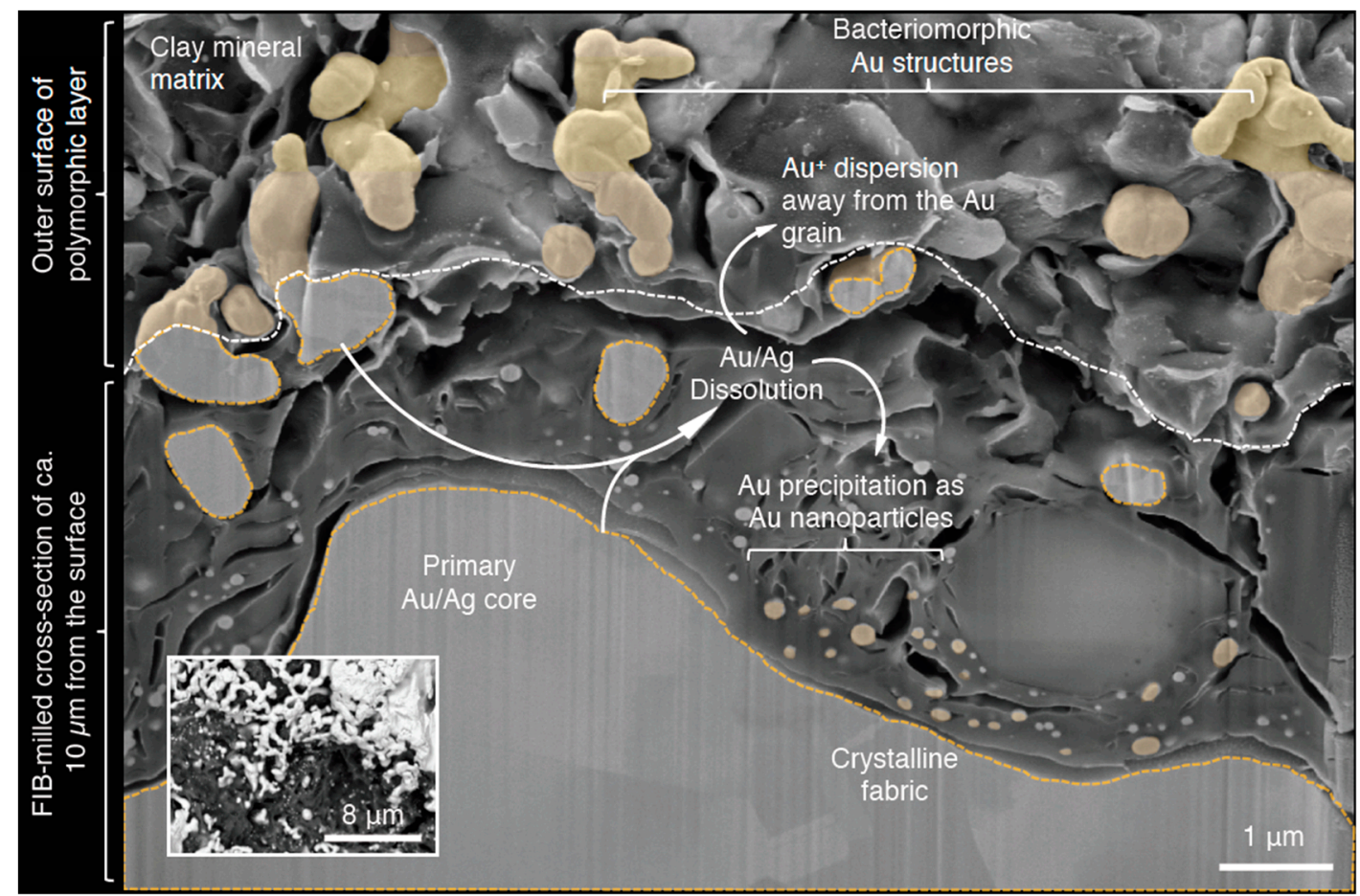

Figure 3. A schematic diagram of the Au biogeochemical cycle occurring at the surface of a placer Au particle, using a false-color SE SEM micrograph of a focus-ion-beam (FIB)-milled cross-section through a polymorphic layer: the interface where Au dissolution and reprecipitation processes occur. A BSC SEM micrograph of an above view of the polymorphic layer (inset). Bacteriomorphic Au structures are interpreted to be part of the primary particle core, as both contain an Au/Ag crystalline fabric. Gold/Ag dissolution lead to the reduced size of the primary core and the formation of bacteriomorphic structures. Intuitively, these structures would eventually be completely dissolved over time. Solubilized Au can be "lost" to the surrounding environment or can be precipitated as Au nanoparticles. The accumulation and aggregation of pure Au nanoparticles can lead to the development of Au-enriched rims. Overall, Au-biogeochemical-cycling contributes to the transformation of placer Au particles.

\section{Secondary Gold Transport and Kinetics of Gold Biogeochemical Cycling}

As previously highlighted, microbes contribute to the dissolution and precipitation of $\mathrm{Au}$. Evidence of this biogeochemical, Au cycle is supported by the structure and chemistry of placer Au particles and the functional capabilities of the biofilms detected on them. Since Au nanoparticles are formed from the reduction of soluble-Au complexes, the mobility of Au nanoparticles is also worth considering. In addition to microbes, various clay minerals, S- or Fe-bearing complexes, and other minerals have been shown to act as reducing agents for soluble-Au complexes, leading to the formation of Au nanoparticles [82-86]. Therefore, it is reasonable to suggest that in the natural environment Au nanoparticles are mobile within hydrogeological regimes. However, organic material, clays, and Fe-bearing minerals have also been shown to readily adsorb Au nanoparticles, rendering them immobile [87-89]. Biofilms act like glue, by trapping nanophase Au particles and gradually accumulating more Au nanoparticles over time. When these Au-encrusted biofilms are subjected to sedimentation processes, the accumulated Au nanoparticles become aggregated into larger nugget-size particles [90]. The formation of these Au particles from biogeochemically-produced, Au nanoparticles suggests that there are some Au particles that are completely composed of secondary $\mathrm{Au}$ in the natural environment.

A better understanding of the dynamics of Au occurrence (i.e., soluble-Au complexes, Au particles, and Au nanoparticles), as well as Au mobility within hydrogeological regimes, will provide the opportunity to assess the kinetics of Au-biogeochemical-cycling in any given environment. Of the two 
processes constituting the biogeochemical cycling of $\mathrm{Au}$, we have seen that Au reprecipitation occurs rapidly. Therefore, the Au dissolution process can be considered the rate-limiting step. The formation of Au nanoparticles from the reduction of soluble-Au complexes produces a normal distribution of nanophase, pseudo-spheres of varying sizes. Variation in nanoparticle sizes depends on the concentration of soluble $\mathrm{Au}$, as well as the availability of a reducing agent [91]. In some Au particles, the sizes of Au nanoparticles have a multimodal distribution, suggesting that punctuated episodes of Au-particle dissolution and reprecipitation likely occurred [66]. For example, from a subtropical-placer environment, it has been determined that the duration of one biogeochemical cycle of Au was $7.64 \pm 4.06$ years [66]. From a geological perspective, this is extraordinarily fast. Therefore, it is worth considering how much Au could be dissolved and subsequently re-precipitated during a single cycle or how long it could take for an entire primary Au particle to be completely transformed. Relict structures of Au-dissolution and reprecipitation processes have been observed from a variety of Au particles from around the globe $[17,54,62,64,66,67,81,92]$; however, the kinetics of biogeochemical-Au-cycling would intuitively be variable, as each depositional environment has its own unique physiochemical, climatic, and biological characteristics. Additionally, hydromechanical factors also have an influence on the mobility and distribution of placer Au particles and soluble Au complexes. It is also important to note that microbes also have an influence on the biogeochemistry of other precious metals, such as platinum and silver [33,93-95]. Therefore, it is reasonable to suggest that the kinetic mobility of Au-biogeochemical-cycling could act as a model for other precious metals.

\section{Conclusions}

Gold is a precious metal that has been valued since antiquity for its stored value and aesthetic qualities. The element's unique physical and chemical properties have arguably been the axiom for its rich and colorful history in research and in the desire to discover new sources to supply our self-generated demand. With increasing utilization of $\mathrm{Au}$ in modern technological and biomedical applications, Au will continue to be appreciated beyond aesthetics. Hence, more interdisciplinary, geomicrobiological research, whether it be geologically- or biologically-focused, is important for understanding the dynamics of $\mathrm{Au}$. In this mini-review, we have briefly discussed how microbes contribute to global Au-biogeochemical-cycling under surface and near-surface conditions. We have also discussed how the perpetuity of this cycle existed in the past and could continue into the future. In geomicrobiological research of $\mathrm{Au}$ (or any studies involving microbe-mineral interactions), it is important to think of the "big picture" and keep an "open mind," as data can be interpreted from different perspectives. As we reflect upon some of the research involving microbe-mineral interactions, one can develop a general appreciation of time. Our valuing of time depends on how we measure and use it: Whether it be for understanding microbially-catalyzed Au dissolution/precipitation processes, estimating the kinetics of Au-particle transformation, or advancing the field of Au-geomicrobiology. As such, the timeless quality of Au itself transcends the socioeconomic and cultural value we project onto it.

Author Contributions: Conceptualization, J.S. and F.R.; Writing-Original Draft Preparation, J.S. and F.R.; Writing-Review \& Editing, J.S. and F.R.; Visualization, J.S.; Funding Acquisition, F.R.

Funding: This review was made possible through the support of the Australian Research Council Future Fellowship (ARC-FT100150200) granted to F.R.

Acknowledgments: SEM imaging was performed at the Western Nanofabrication Facility (Western University, Canada) and at the Center for Microscopy and Microanalysis, a part of the Australian Microscopy and Microanalysis Research Facility (The University of Queensland, Australia). TEM imaging was performed at the Biotron Integrated Microscopy Facility (Western University, Canada). The authors would like to extend their gratitude to G. Southam and the members of Vale-UQ Geomicrobiology Laboratory (The University of Queensland), as well as the Microbes and Heavy Metal Group (The University of Adelaide), for their support.

Conflicts of Interest: The authors declare no conflict of interest. 


\section{References}

1. Frimmel, H.E. Earth's continental crustal gold endowment. Earth Planet. Sci. Lett. 2008, 267, 45-55. [CrossRef]

2. Pitcairn, I.K. Background concentrations of gold in different rock types. Appl. Earth Sci. 2013, 120, 31-38. [CrossRef]

3. Boyle, R.W. The geochemistry of gold and its deposits. Geol. Surv. Can. Bull. 1979, 280, 1-54.

4. Mossman, D.J.; Dyer, B.D. The geochemistry of Witwatersrand-type gold deposits and the possible influence of ancient prokaryotic communities on gold dissolution and precipitation. Precambrian Res. 1985, 30, 303-319. [CrossRef]

5. Sillitoe, R.H. Major gold deposits and belts of the North and South American Cordillera: Distribution, tectonomagmatic settings, and metallogenic considerations. Econ. Geol. 2008, 103, 663-687. [CrossRef]

6. Sillitoe, R.H.; Lorson, R. Epithermal gold-silver-mercury deposits at Paradise Peak, Nevada: Ore controls, porphyry gold association, detachment faulting and supergene oxidation. Econ. Geol. 1994, 89, 1228-1248. [CrossRef]

7. Reith, F. Life in the deep subsurface. Geology 2011, 39, 287-288. [CrossRef]

8. Rothschild, L.J.; Mancinelli, R. Life in extreme environments. Nature 2001, 409, 1092-1101. [CrossRef] [PubMed]

9. MacLean, L.C.; Tyliszczak, T.; Gilbert, P.U.; Zhou, D.; Pray, T.J.; Onstott, T.C.; Southam, G. A high-resolution chemical and structural study of framboidal pyrite formed within a low-temperature bacterial biofilm. Geobiology 2008, 6, 471-480. [CrossRef] [PubMed]

10. Wanger, G.; Southam, G.; Onstott, T.C. Structural and Chemical Characterization of a Natural Fracture Surface from 2.8 Kilometers Below Land Surface: Biofilms in the Deep Subsurface. Geomicrobiol. J. 2006, 23, 443-452. [CrossRef]

11. Southam, G.; Saunders, J.A. The geomicrobiology of ore deposits. Econ. Geol. 2005, 100, 1067-1084. [CrossRef]

12. Knowles, C.J. Microorganisms and cyanide. Bacteriol. Rev. 1976, 40, 652-680. [PubMed]

13. Southam, G.; Beveridge, T.J. The in vitro formation of placer gold by bacteria. Geochim. Cosmochim. Acta 1994, 58, 4527-4530. [CrossRef]

14. Reith, F.; Lengke, M.F.; Falconer, D.; Craw, D.; Southam, G. The geomicrobiology of gold. ISME J. 2007, 1, 567-584. [CrossRef] [PubMed]

15. Shuster, J.; Bolin, T.; MacLean, L.C.; Southam, G. The effect of iron-oxidising bacteria on the stability of gold (I) thiosulfate complex. Chem. Geol. 2014, 376, 52-60. [CrossRef]

16. Shuster, J.; Marsden, S.; Maclean, L.C.; Ball, J.; Bolin, T.; Southam, G. The immobilization of gold from gold (III) chloride by a halophilic sulfate-reducing bacterial consortium. Geol. Soc. Lond. Spec. Pub. 2013, 393, 249-263. [CrossRef]

17. Reith, F.; Rogers, S.L.; McPhail, D.C.; Webb, D. Biomineralization of gold: Biofilms on bacterioform gold. Science 2006, 313, 233-236. [CrossRef] [PubMed]

18. Rawlings, D.E. Heavy metal mining using microbes. Annu. Rev. Microbiol. 2002, 56, 65-91. [CrossRef] [PubMed]

19. Rawlings, D.E.; Johnson, D.B. The microbiology of biomining: Development and optimization of mineral-oxidizing microbial consortia. Microbiology 2007, 153, 315-324. [CrossRef] [PubMed]

20. Zammit, C.M.; Cook, N.; Brugger, J.; Ciobanu, C.L.; Reith, F. The future of biotechnology for gold exploration and processing. Miner. Eng 2012, 32, 45-53. [CrossRef]

21. Reith, F.; Brugger, J.; Zammit, C.; Nies, D.; Southam, G. Geobiological cycling of gold: From fundamental process understanding to exploration solutions. Minerals 2013, 3, 367-394. [CrossRef]

22. Puddephatt, R.J. The Chemistry of Gold. Topics in Inorganic and General Chemistry: Monograph 16; Elsevier: Amsterdam, The Netherlands, 1978.

23. Williams-Jones, A.E.; Bowell, R.J.; Migdisov, A.A. Gold in solution. Elements 2009, 5, 281-287. [CrossRef]

24. Ta, C.; Reith, F.; Brugger, J.; Pring, A.; Lenehan, C.E. Analysis of gold(I/III)-complexes by HPLC-ICP-MS demonstrates gold (III) stability in surface waters. Environ. Sci. Technol. 2014, 48, 5737-5744. [CrossRef] [PubMed]

25. Ta, C.; Brugger, J.; Pring, A.; Hocking, R.K.; Lenehan, C.E.; Reith, F. Effect of manganese oxide minerals and complexes on gold mobilization and speciation. Chem. Geol. 2015, 407, 10-20. [CrossRef]

26. Mann, A.W. Mobility of gold and silver in lateritic weathering profiles: Some observations from Western Australia. Econ. Geol. 1984, 79, 38-49. [CrossRef] 
27. Webster, J.G. The solubility of gold and silver in the system Au-Ag-S-O $\mathrm{O}_{2}-\mathrm{H}_{2} \mathrm{O}$ at $25{ }^{\circ} \mathrm{C}$ and 1 atm. Geochim. Cosmochim. Acta 1986, 50, 1837-1845. [CrossRef]

28. Benedetti, M.; Boulegue, J. Mechanism of gold transfer and deposition in a supergene environment. Geochim. Cosmochim. Acta 1991, 55, 1539-1547. [CrossRef]

29. Kerr, G.; Craw, D. Mineralogy and geochemistry of biologically-mediated gold mobilisation and redeposition in a semiarid climate, southern New Zealand. Minerals 2017, 7, 147. [CrossRef]

30. Schippers, A.; Sand, W. Bacterial leaching of metal sulfides proceeds by two indirect mechanisms via thiosulfate or via polysulfides and sulfur. Appl. Environ. Microbiol. 1999, 65, 319-321. [PubMed]

31. Vlassopoulos, D.; Wood, S.A. Gold speciation in natural waters: I. Solubility and hydrolysis reactions of gold in aqueous solution. Geochim. Cosmochim. Acta 1990, 54, 3-12. [CrossRef]

32. Leybourne, M.I.; Goodfellow, W.D.; Boyle, D.R.; Hall, G.E.M. Form and distribution of gold mobilized into surface waters and sediments from a gossan tailings pile, Murray Brook massive sulphide desposit, New Brunswick Canada. Appl. Geochem. 2000, 15, 629-646. [CrossRef]

33. Campell, S.C.; Olson, G.J.; Clark, T.R.; McFetters, G. Biogenic production of cyanide and its application to gold recovery. J. Ind. Microbiol. Biotechnol. 2001, 26, 134-139. [CrossRef]

34. Fairbrother, L.; Shapter, J.; Brugger, J.; Southam, G.; Pring, A.; Reith, F. Effect of the cyanide-producing bacterium Chromobacterium violaceum on ultraflat Au surfaces. Chem. Geol. 2009, 265, 313-320. [CrossRef]

35. Baker, W.E. The rold of humic acid in the transport of gold. Geochim. Cosmochim. Acta 1978, 42, 645-649. [CrossRef]

36. Bowell, R.J. Supergene gold mineralogy at Ashanti, Ghana: Implications for the supergene behaviour of gold. Mineral. Mag. 1992, 56, 545-560. [CrossRef]

37. Bowell, R.J.; Gize, A.P.; Foster, R.P. The role of fulic acid in the supergene migration of gold in tropical rain forest soils. Geochim. Cosmochim. Acta 1993, 57, 4179-4190. [CrossRef]

38. Butt, C.R.M. Supergene gold deposits. AGSO J. Aust. Geol. Geophys. 1998, 14, 89-96.

39. Fetzer, W.G. Humic acids and true organic acids as solvents of minerals. Econ. Geol. 1946, 41, 47-56. [CrossRef]

40. Freise, F.W. The transportation of gold by organic underground solutions. Econ. Geol. 1931, 26, 421-431. [CrossRef]

41. Carey, M.L.; McPhail, D.C.; Taufen, P.M. Groundwater flow in playa lake environments-Impact on gold and pathfinder element distributions in groundwaters surrounding mesothermal gold deposits, St. Ives area, Eastern Goldfields, Western Australia. Geochem. Explor. Environ. Anal. 2003, 3, 57-71. [CrossRef]

42. Goldschmidt, V.M. The principles of distribution of chemical elements in minerals and rocks. J. Chem. Soc. 1937, 655-673. [CrossRef]

43. Lowenstam, H.A. Minerals formed by organisms. Science 1981, 211, 1126-1131. [CrossRef] [PubMed]

44. Beveridge, T.J.; Fyfe, W.S. Metal fixation by bacterial cell walls. Can. J. Earth Sci. 1985, 22, $1893-1898$. [CrossRef]

45. Daughney, C.J.; Fein, J.B.; Yee, N. A comparison of the thermodynamics of metal adsorption onto two common bacteria. Chem. Geol. 1998, 144, 161-176. [CrossRef]

46. Southam, G.; Beveridge, T.J. The occurrence of sulfur and phosphorus within bacteriall derived crystalline and pseudocrastalline octahedral gold formed in vitro. Geochim. Cosmochim. Acta 1996, 60, 4369-4376. [CrossRef]

47. Kashefi, K.; Tor, J.M.; Nevin, K.P.; Lovley, D.R. Reductive precipitation of gold by dissimilatory Fe(III)-reducing bacteria and archaea. Appl. Environ. Microbiol. 2001, 67, 3275-3279. [CrossRef] [PubMed]

48. Lengke, M.F.; Fleet, M.E.; Southam, G. Bioaccumulation of gold by filamentous cyanobacteria between 25 and $200{ }^{\circ}$ C. Geomicrobiol. J. 2006, 23, 591-597. [CrossRef]

49. Lengke, M.F.; Southam, G. Bioaccumulation of gold by sulfate-reducing bacteria cultured in the presence of gold(I)-thiosulfate complex. Geochim. Cosmochim. Acta 2006, 70, 3646-3661. [CrossRef]

50. Lengke, M.F.; Southam, G. The deposition of elemental gold from gold (I) thiosulfate complexes mediated by sulfate-reducing bacterial conditions. Econ. Geol. 2007, 102, 109-126. [CrossRef]

51. Kenney, J.P.L.; Song, Z.; Bunker, B.A.; Fein, J.B. An experimental study of Au removal from solution by non-metabolizing bacterial cells and their exudates. Geochim. Cosmochim. Acta 2012, 87, 51-60. [CrossRef]

52. Song, Z.; Kenney, J.P.L.; Fein, J.B.; Bunker, B.A. An X-ray Absorption Fine Structure study of Au adsorbed onto the non-metabolizing cells of two soil bacterial species. Geochim. Cosmochim. Acta 2012, 86, 103-117. [CrossRef] 
53. Fairbrother, L. Cupriavidus Metallidurans and the Biomineralization of Gold: The Role of Bacteria in the Formation of Secondary Gold on Grains in the Australian Regolith. Ph.D. Thesis, Flinders University, Adelaide, Australia, 2013.

54. Fairbrother, L.; Etschmann, B.; Brugger, J.; Shapter, J.; Southam, G.; Reith, F. Biomineralization of gold in biofilms of Cupriavidus metallidurans. Environ. Sci. Technol. 2013, 47, 2628-2635. [CrossRef] [PubMed]

55. Karthikeyan, S.; Beveridge, T. Pseudomonas aeruginosa biofilms react with and precipitate toxic soluble gold. Environ. Microbiol. 2002, 4, 667-675. [CrossRef] [PubMed]

56. Johnston, C.W.; Wyatt, M.A.; Li, X.; Ibrahim, A.; Shuster, J.; Southam, G.; Magarvey, N.A. Gold biomineralization by a metallophore from a gold-associated microbe. Nat. Chem. Biol. 2013, 9, 241-243. [CrossRef] [PubMed]

57. Butof, L.; Wiesemann, N.; Herzberg, M.; Altzschner, M.; Holleitner, A.; Reith, F.; Nies, D.H. Synergistic gold-copper detoxification at the core of gold biomineralisation in cupriavidus metallidurans. Metallomics 2018, 10, 278-286. [CrossRef] [PubMed]

58. Wiesemann, N.; Butof, L.; Herzberg, M.; Hause, G.; Berthold, L.; Etschmann, B.; Brugger, J.; Martinez-Criado, G.; Dobritzsch, D.; Baginsky, S.; et al. Synergistic toxicity of copper and gold compounds in Cupriavidus metallidurans. Appl. Environ. Microbiol. 2017, 83, 1-17. [CrossRef] [PubMed]

59. Reith, F.; Etschmann, B.; Grosse, C.; Moors, H.; Benotmane, M.A.; Monsieurs, P.; Grass, G.; Doonan, C.; Vogt, S.; Lai, B.; et al. Mechanisms of gold biomineralization in the bacterium Cupriavidus metallidurans. Proc. Natl. Acad. Sci. USA 2009, 106, 17757-17762. [CrossRef] [PubMed]

60. Etschmann, B.; Brugger, J.; Fairbrother, L.; Grosse, C.; Nies, D.H.; Martinez-Criado, G.; Reith, F. Applying the Midas touch: Differing toxicity of mobile gold and platinum complexes drives biomineralization in the bacterium Cupriavidus metallidurans. Chem. Geol. 2016, 438, 103-111. [CrossRef]

61. Rea, M.A.; Zammit, C.; Reith, F. Bacterial biofilms on gold grains-Implications for geomicrobial transformations of gold. FEMS Microbiol. Ecol. 2016, 92, 1-12. [CrossRef] [PubMed]

62. Reith, F.; Fairbrother, L.; Nolze, G.; Wilhelmi, O.; Clode, P.L.; Gregg, A.; Parsons, J.E.; Wakelin, S.A.; Pring, A.; Hough, R.; et al. Nanoparticle factories: Biofilms hold the key to gold dispersion and nugget formation. Geology 2010, 38, 843-846. [CrossRef]

63. Reith, F.; McPhail, D.C. Effect of resident microbiota on the solubilization of gold in soil from the Tomakin Park Gold Mine, New South Wales, Australia. Geochim. Cosmochim. Acta 2006, 70, 1421-1438. [CrossRef]

64. Reith, F.; Stewart, L.; Wakelin, S.A. Supergene gold transformation: Secondary and nano-particulate gold from southern New Zealand. Chem. Geol. 2012, 320, 32-45. [CrossRef]

65. Reith, F.; Wakelin, S.A.; Gregg, A.L.; Mumm, A.S. A microbial pathway for the formation of gold-anomalous calcrete. Chem. Geol. 2009, 258, 315-326. [CrossRef]

66. Shuster, J.; Reith, F.; Cornelis, G.; Parsons, J.E.; Parsons, J.M.; Southam, G. Secondary gold structures: Relics of past biogeochemical transformations and implications for colloidal gold dispersion in subtropical environments. Chem. Geol. 2017, 450, 154-164. [CrossRef]

67. Rea, M.A.; Standish, C.D.; Shuster, J.; Bissett, A.; Reith, F. Progressive biogeochemical transformation of placer gold particles drives compositional changes in associated biofilm communities. FEMS Microbiol. Ecol. 2018, 94, fiy080. [CrossRef] [PubMed]

68. Townley, B.K.; Herail, G.; Maksaev, V.; Palacios, C.; de Parseval, P.; Sepulveda, F.; Orellana, R.; Rivas, P.; Ulloa, C. Gold grain morphology and composition as an exploration tool-application to gold exploration in covered areas. Geochem. Explor. Environ. Anal. 2003, 3, 29-38. [CrossRef]

69. Kesler, S.E.; Chryssoulis, S.L.; Simon, G. Gold in poryphyry copper deposits: Its abundance and fate. Ore Geol. Rev. 2002, 21, 103-124. [CrossRef]

70. Bonev, I.K.; Kerestedjian, T.; Atanassova, R.; Andrew, C.J. Morphogenesis and composition of native gold in the Chelopech volcanic-hosted Au-Cu epithermal deposit, Srednogorie zone, Bulgaria. Miner. Depos. 2002, 37, 614-629. [CrossRef]

71. Hough, R.M.; Butt, C.R.M.; Buhner, J.F. The crystallography, metallography and composition of gold. Elements 2009, 5, 297-302. [CrossRef]

72. Zavalía, F.M.; Craig, J.R.; Solberg, T.N. Duranusite, product of realgar alteration, Mina Capillitas, Argentina. Can. Mineral. 1999, 37, 1255-1259.

73. Zavalía, F.M.; Craig, J.R. Tellurium and precious-metal ore minerals at Mina Capillitas, Northwestern Argentina. Neues Jahrbuch für Mineralogie Monatshefte 2004, 4, 176-192. [CrossRef] 
74. Sampson, M.I.; Phillips, C.V.; Ball, A.S. Investigation of the attachment of Thiobacillus ferrooxidans to mineral sulfides using scanning electron microscopy analysis. Miner. Eng. 2000, 13, 643-656. [CrossRef]

75. Jones, R.A.; Koval, S.F.; Nesbitt, H.W. Surface alteration of arsenopyrite (FeAsS) by Thiobacillus ferrooxidans. Geochim. Cosmochim. Acta 2003, 67, 955-965. [CrossRef]

76. Thurston, R.S.; Mandernack, K.W.; Shanks, W.C. Laboratory chalcopyrite oxidation by Acidithiobacillus ferrooxidans: Oxygen and sulfur isotope fractionation. Chem. Geol. 2010, 269, 252-261. [CrossRef]

77. Shuster, J.; Lengke, M.F.; Zavalía, F.M.; Southam, G. Floating gold grains and nanophase particles produced from the biogeochemical weathering of a gold-bearing ore. Econ. Geol. 2016, 111, 1485-1494. [CrossRef]

78. Reith, F.; Rea, M.A.D.; Sawley, P.; Zammit, C.M.; Nolze, G.; Reith, T.; Rantanen, K.; Bissett, A. Biogeochemical cycling of gold: Transforming gold particles from arctic Finland. Chem. Geol. 2018, 483, 511-529. [CrossRef]

79. Reith, F.; Etschmann, B.; Dart, R.C.; Brewe, D.L.; Vogt, S.; Mumm, A.S.; Brugger, J. Distribution and speciation of gold in biogenic and abiogenic calcium carbonates-Implications for the formation of gold anomalous calcrete. Geochim. Cosmochim. Acta 2011, 75, 1942-1956. [CrossRef]

80. Craw, D.; Lilly, K. Gold nugget morphology and geochemical environments of nugget formation, southern New Zealand. Ore Geol. Rev. 2016, 79, 301-315. [CrossRef]

81. Shuster, J.; Johnston, C.W.; Magarvey, N.A.; Gordon, R.A.; Barron, K.; Banerjee, N.R.; Southam, G. Structural and chemical characterization of placer gold grains: Implications for bacterial contributions to grain formation. Geomicrobiol. J. 2015, 32, 158-169. [CrossRef]

82. Cohen, D.R.; Waite, T.D. Interaction of aqueous Au species with goethite, smectite and kaolinite. Geochem. Explor. Environ. Anal. 2004, 4, 279-287. [CrossRef]

83. Hanlie, H.; Liyun, T. Deposition of gold on kaolinite surfaces from $\mathrm{AuCl}_{4}$ - solution. Geochem. Int. 2006, 44, 1246-1249.

84. Hanlie, H.; Zhengyi, F.; Xinmin, M. The adsorption of $\left[\mathrm{Au}(\mathrm{HS})_{2}\right]^{-}$on kaolinite surfaces: Quantum chemistry calculations. Can. Mineral. 2001, 39, 1591-1596. [CrossRef]

85. Mohammadnejad, S.; Provis, J.L.; van Deventer, J.S. Gold sorption by silicates in acidic and alkaline chloride media. Int. J. Mineral. Process. 2011, 100, 149-156. [CrossRef]

86. Mohammadnejad, S.; Provis, J.L.; van Deventer, J.S. Reduction of gold(III) chloride to gold(0) on silicate surfaces. J. Colloid Interface Sci. 2013, 389, 252-259. [CrossRef] [PubMed]

87. Reith, F.; Cornelis, G. Effect of soil properties on gold- and platinum nanoparticle mobility. Chem. Geol. 2017, 466, 446-453. [CrossRef]

88. Hanlie, H.; Liyun, T.; Qiujuan, B.; Yong, Z. Interface characteristics between colloidal gold and kaolinite surface by XPS. J. Wuhan Univ. Technol. Mater. Sci. Ed. 2006, 21, 90-93. [CrossRef]

89. Zhu, L.; Letaief, S.; Liu, Y.; Gervais, F.; Detellier, C. Clay mineral-supported gold nanoparticles. Appl. Clay Sci. 2009, 43, 439-446. [CrossRef]

90. Shuster, J.; Southam, G. The in-vitro "growth" of gold grains. Geology 2014, 43, 79-82. [CrossRef]

91. Turkevich, J.; Stevenson, P.C.; Hillier, J. A study of the nucleation and growth processes in the synthesis of colloidal gold. Discuss. Faraday Soc. 1951, 11, 55-75. [CrossRef]

92. Fairbrother, L.; Brugger, J.; Shapter, J.; Laird, J.S.; Southam, G.; Reith, F. Supergene gold transformation: Biogenic secondary and nano-particulate gold from arid Australia. Chem. Geol. 2012, 320, 17-31. [CrossRef]

93. Campbell, G.; MacLean, L.; Reith, F.; Brewe, D.; Gordon, R.; Southam, G. Immobilisation of platinum by cupriavidus metallidurans. Minerals 2018, 8, 10. [CrossRef]

94. Shuster, J.; Reith, F.; Izawa, M.; Flemming, R.; Banerjee, N.; Southam, G. Biogeochemical cycling of silver in acidic, weathering environments. Minerals 2017, 7, 218. [CrossRef]

95. Reith, F.; Zammit, C.M.; Shar, S.S.; Etschmann, B.; Bottrill, R.; Southam, G.; Ta, C.; Kilburn, M.; Oberthür, T.; Ball, A.S.; et al. Biological role in the transformation of platinum-group mineral grains. Nat. Geosci. 2016, 9, 294. [CrossRef]

(C) 2018 by the authors. Licensee MDPI, Basel, Switzerland. This article is an open access article distributed under the terms and conditions of the Creative Commons Attribution (CC BY) license (http://creativecommons.org/licenses/by/4.0/). 